の場合，前述の熱分析の結果より，領域 B及びCでは砶 化物が晶出する可能性が高い.

第 2 段階では，粉末のデンドライト境界において選択 的に融液が形成されると同時に固相が成長する段階を示 す.第 1 段階において領域Cに形成された矹化物は周囲 の液相からボロンを吸収することにより成長する。この ため矹化物周辺のボロンの濃度が低下すると，ボロン濃 度の高い領域 $\mathrm{A}$ から領域Cへボロンが供給される．供給 されたボロンを平衡組成のボロン濃度に希釈するように 領域Cではデンドライト境界がさらに溶融し，選択的に 粉末内のデンドライト境界の液化が進行する．また，同 時に形成された硼化物も成長する。一方，領域 Aではボ ロンが領域 Cへ流出することにより，平衡のボロン濃度 を保持するために，粉末側から固相が成長する.

第 3 段階では, 粉末の中心のデンドライト境界まで液 化が進行し，デンドライト境界周辺の液化が進行し，そ の液相幅が広がる段階を示している。第 2 段階と同樣な 機構でデンドライト境界周辺の液化が進行し, 同時に, 矹化物が形成され，領域 $\mathrm{A}$ の液相が消隇している.

粉末を用いた液相インサート金属拡散接合における液 相の消隇は以上の上うな機構で液相中のポロンが粉末内 の矹化物の形成に消費されることにより達成されるもの と推察される。

\section{6. 結論}

本報告では，合金元素を用いた液相インサート金属挔 散接合の接合現象を明確にするため，溶融インサート金 属による粉末の溶融現象並びに液相の消隇現象について 検討を行い，本接合法における等温凝固機構についての 考察を行った. 得られた実験結果を要約すると以下のよ
うになる。

（1）接合初期段階においては，保持時間に関係なく粉 末表面に微細な明化物が約 $5 \mu \mathrm{m}$ の厚さで形成された。 これは溶融インサート金属が㸮末表層部を均一に溶融し た結果形成されたものと推察された。

また，粉末の粒界及びデンドライト境界に沿って矹化 物が形成され保持時間の増加に伴い粒界の嗍化物の生成 領域は粉末の中心部へ向かって進行し，その粒界幅も広 くなることが認められた。これは溶融インサート金属が 粉末のデンドライト境界に浸入したことによるものと推 察された。

（2）等温保持過程で粉末間の液相中のボロンは，粉末 内の硼化物の形成に消費される。その結果として, 液相 が消滅し，等温凝固が進行するものと推察された。

\section{謝 辞}

本研究の遂行に際し熱心に協力された長谷和邦工学士 に心から感謝いたします。また，材料の面で御援助，御 協力いただいた，三菱マテリアル(粈及び福田金属䇴粉工 業(侏に対し厚く御礼申します。

\section{参 考 文 献}

1）中尾嘉邦，西本和俊，簿崎賢二，姜晶允，重田春樹：合金粉末を 用いた液相インサート金属㹡散接合法の開発, 溶接学会論文集, 9-4 (1991).

2) (社溶接学会溶接冶金研究委員会編：鉄鋼溶接部の破面写真集, 黒木出版。

3）中尾嘉邦, 西本和俊, 策崎蜸二, 姜晶允：液相インサート金属㹡 散接合にお汀る等温凝固過程の解析, 溶接学会論文集, 7-2 (1989), p. 213 .

\title{
インプラント型ねじり試験による溶射部材の界面強度の 評価試験方法の提案と一考察*
}

\author{
寺崎 俊夫**, 秋山 哲也**, 金子 友義***, 久田 秀夫***
}

\author{
Proposal of Implant Type Torsion Test for Estimating Adhesive Strength \\ of Sprayed Coatings*
}

by Toshio Terasaki**, Tetsuya Akiyama**, Tomoyoshi Kaneko*** and Hideo Hisada***

This paper deals with the testing method for estimating the adhesive strength of sprayed coatings by the Implant type specimen loaded torsion because sprayed coatings usually are loaded in shear stress. The shearing strength obtained from this testing method was analysed based on the concept of energy release rate. To obtain the shearing strength of sprayed coatings, we made a new testing machine which can detect as a small stress as a strength of sprayed coatings. Energy release rate was calculated using numerical analysis. The result of the strength obtained from this method was reproducible to plus or minus $10 \%$ of a stress. From numerical analysis, the conditions for specimen size, in which the energy release rate caused by the residual stress of each specimen should be equal, was clarified. The energy release rate was useful to estimate the adhesive strength of sprayed coatings.

\footnotetext{
*原稿受付 平成 3 年 1 月 7 日 平成 2 年度秋季全国大会で発表

**正 貣 九州工業大学 Member, Kyushu Institute of Technology 小松製作所 Komatsu Co., Ltd.
} 
Key Words : spraying coating, torsion test, implant test, residual stress, energy release rate

\section{1. 緒}

言

溶射されたサブストレイト(以後では溶射部材と呼ぶ) の界面強度を小型の試験片により評価できることは，実 際の製品の強度を正しく評価する上で重要である．溶射 部材の強度評価方法として, JIS 規格" では, 特定の形状 の試験片を用いた引張試験が規格化されている.しかし， 多くの溶射部材が使用中に破損する荷重形態はせん断荷 重であり，引張荷重により破損する例は少ないと考えら れる. 従って, せん断荷重による試験方法が実際の製品 の強度を評価する上で必要と思われる，せん断荷重試験 として，2，30方法が提案されているが2,3), 従来の試 験方法では, 界面強度を測定していると考えられない問 題や実験值の信頼性に問題がある.

一方，異材継手の強度評価は力学的にはまだ確立され ていない. 現在, 多くの研究者により研究され, 種々の 知見が報告されている4 . 服部ら 場に注目し，線形破壊力学の概念と同様にして，応力特 異場の応力の強さを示す係数 $K$ (き裂の力学では応力抬 大係数と呼ばれる) と特異応力分布の指数を $t$ (き裂では 1/2)を用いて, 界面強度の評価に成功している. 結城ら6) はき裂を有する異材継手の強度評価をエネルギー解放率 で取扱い, 破壞強度や疲労強度の評価に成功している。 井上ら》 は応力特異場の応力分布がき裂と同様に $1 / 20$ 傾きに従うことを示して, 応力の強さ $K$ のみに注目し て, 強度評価している。しかし，これらの報告では残留 応力に関する考虑がなされていない. 溶射部材では溶射 による熱履歴により残留応力が生じるため, 残留応力に 注意して, 強度評価をする必要がある。また，著者らは 前報8,99 で溶射部材に生じる特異応力場の残留応力分布 及び外荷重による応力分布が一つの応力の強さ $K \omega$ み で評価できないことを明かにした，従って，強度評洒に 応力の強さ $K$ を用いる場合には制限条件が存在すると 思われる。

本研究では，溶射部材の界面がせん断荷重により破壊 する試験方法として，ねじり試験を取り上げた。そして， 溶射部材のねじり試験機が具備しなければならない条件 を倹討して，信頼性の高い溶射部材の界面強度が得られ るねじり試験片を考案した。次に，強度評価パラメータ として, 計算值の精度の高いエネルギー解放率のを取り 上げ，9值が強度評価のパラメータとして，工学的に有 効か否かを実験及び既発表のデーダを用いて検討し た.

\section{2. 強度評価試験方法}

\section{1 インプラント型ねじり試験の特徴}

荷重負荷形式がせん断の試験方法を検郡するために， 従来の試験方法の例を Fig. 1 (a)，(b)，(c) (2,3) に示す. (a), (b)は軸荷重を，(c)は格じり荷重を負荷する。(a)では溶射 皮膜の圧縮破壊強度がせん断強度上り大きくなければ, 得られた強度が意味を持たないこと，溶射皮膜の界面で 破壊する保証がないことなど，得られた夹験值には界面 強度以外の強度が含まれる欠点が举げられている2!.(b) では純せん断が負荷し難く, 得られた強度が界面強度と 見なせない欠点がある。また，(b)，(c)では接着㓩を用い

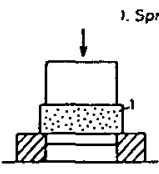

(a)

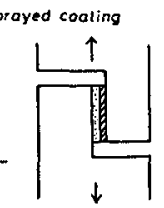

(b)

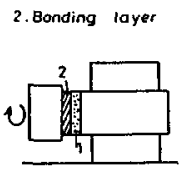

(c)

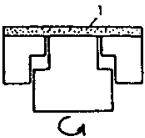

(d)
Fig. 1 Testing method of shearing strength of sprayed coatings.

ているため，接着凧の強度よりも高い強度の溶射部材の 強度が測定できなかったり，溶射皮膜に浸透した接着剂 の影響が指摘されている2\}. 以上の事から，純せん断で， しかも接着剤を用いない試験方法が必要である．本研究 では，接着剤を用いないねじり試験法として (d)に示すイ ンプラント型のねじり試験を提案する。

\section{2 試験片}

Fig. 2 に試験片の形状を示す. 部品 2 の直径 $d$ の穴 に, 直径 $d$ の部品 1 を挿入すると, Fig. 1 (d)に示したイ ンプラント型試験片ができあがる. 部品 1 と部品 2 のク リアランスは半径で $0.1 \mathrm{~mm}$ とした. M6のボルトを用 いて部品 $1 ， 2 ， 3$ を固定し, 部品 $1 ， 2$ の上面を面一 に仕上げ，ブラスティング処理後，プラズマ溶射する. 溶射後, M6のボルトをはずし部品 3 を取り除いた後に, ねじり試験を行う。

本研究では，試験片を軟鐝で作り，直径 $d$ を，10, $15 \mathrm{~mm} の 3$ 種類変化させた. 溶射は, 溶射材料に $50 \% \mathrm{Ni}$ $-50 \% \mathrm{Cr}$ 粉末を用い, 電流 $630 \mathrm{~A}$, 電压 $72 \mathrm{~V}$, アルゴン 55 $\ell / \mathrm{min}$ と水素 $8 \ell / \mathrm{min}$ の混合がスで行った. 皮膜厚さは $0.5 \mathrm{~mm}$ を目標とした。

\section{3 試験機}

試験機は, 試験片にねじり荷重のみを与え, 引張荷重 などを与えることが無いように設計しなくてはならな い. また, 破断荷重は, 通常の金属材料の标じり試験に
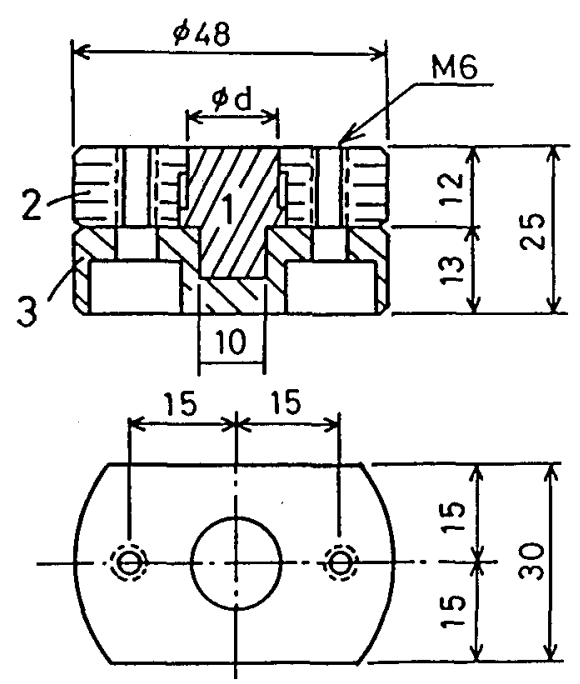

Fig. 2 Torsion testing specimen. 
比べるときわめて低い荷重となる．そこで，試験片は回 転運動のみを拘束され軸方向には自由に動ける試験機を 自作した. Fig. 3(a)に，自作したねじり試験機の概略図を 示す.

ハンドル(1)の回転を, ギヤボックス(2)で咸速し, カッ プリング(3)を通してシャフト(5)へ伝える.シャフト(5)は, ベアリング(4)で支持されている. シャフト(5)から回転を 伝えられた試験片は，シャフト(6)で固定されており，ね じりの荷重を受ける. シャフト(6)は, ロードセル(7)とロ ードセルストッパー8 (80回転運動を固定されているが, スライドベアリング(10)とローラー9)で支持されているた め，軸方向には自由に動ける．ひずみゲージ(11)取り付 けたロードセル(7)の断面係数を小さくすれば，わずかな 荷重でも十分検出できる.

実験では，ロート゚セルに断面が $10 \mathrm{~mm} \times 3 \mathrm{~mm}$ の薄い 鋼の板を用い, 試験片が破断するまでねじり角を0.1度ず つ段階的に増加させ, 試験片にかかる最大せん断応力を 求めた.

Fig. 3 (b)に示す試験片は, 本試験機の荷重負荷形式の 検定に用いた試験片である. 丸棒の中央部の表と裏に付 けた 3 軸のひずみゲージの出力から，ひずみロゼット法 により主応力とその方向を求めた. その結果, 軸方向に は最大せん断応力の $7 \%$ 以下の軸方向の応力が生じる程 度で, ほとんど純せん断であった.

\section{3. 試 験 結 果}

\section{1 ブラスティング処理による試験片の変形}

本試験方法では，溶射皮膜のかみ込みが試験結果に与 える影響はほとんど無いと考えられる. 一方, 試験片の 表面はブラスティングにより塑性変形し, 当初の寸法精 度とは異なった形状に変形される. Fig. 4 に, ブラスティ
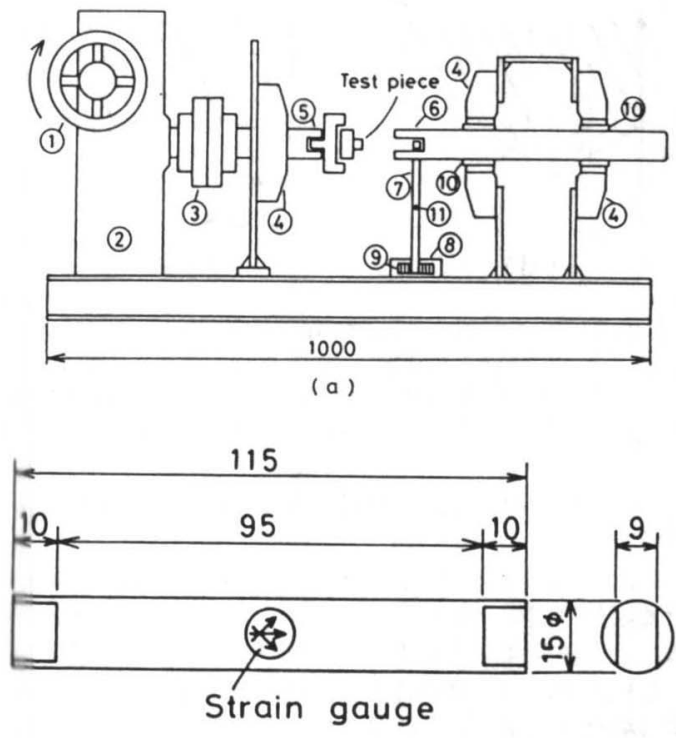

(b)

Fig. 3 Torsion testing machine: (a) assembly of test machine, (b) test piece for the calibration.
ング後の試験片の断面写真を示す. (a)はインプラント試 験片とサポートプレートの境界部, (b)は試験片の端部で ある. (b)より, 試験片の端部は約 $100 \mu \mathrm{m}$ 変形している. (a)では, 試験片同士が接触していることが分かる. 従っ て,この接触部が受け持つ荷重が強度評価に影響する可 能性がある. 一方, この強度は, 後述するようにブラス ティングのみを行った試験片をねじり試験することで正 確に求めることができる.

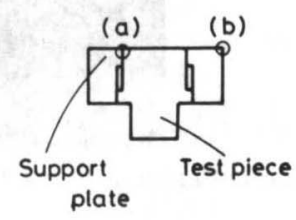

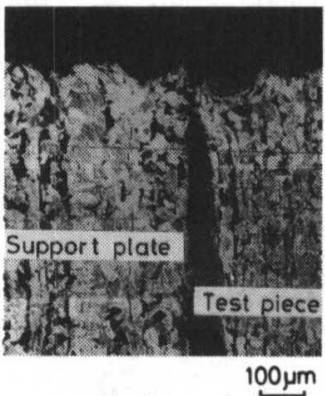

(a)

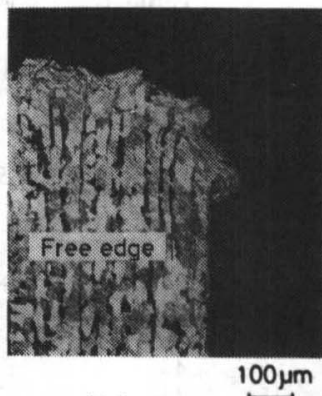

(b)
Fig. 4 Plastic deformation caused by blasting: (a) at the interface between a test piece and support plate, (b) at the corner of a support plate.

\section{2 破断経路}

現実の溶射部材の強度を試験片の実験から求める為に は, 少なくとも現実の溶射部材が破断するのと同じ程度 で, 界面から破壊する必要がある．試験後の破断経路を Fig. 5 に示す. (b)は(a)のインプラント試験片部の拡大図, (c)は(b)の界面部の拡大図である. (c)の溶射皮膜にはブラ スティング面の凹凸が残っており，ブラスティング面に はAで示す部分にのみ溶射皮膜が付着しているだけで, 破断は溶射皮膜とブラスティング面の境界で生じている ことが分かる. 以上の事から，破断が界面で起こったと きの界面強度が本実験方法で得られたと思われる。

\section{3 せん断強度}

溶射部材のねじり試験結果を Table 1 に示す. $d$ は試 験片直径である. $\tau_{\mathrm{b}}$ の欄に, 破断時の最大せん断応力を, 平均値の欄に平均と分散を示す. 最もばらつきが大きい $d=15 \mathrm{~mm}$ でも, $10 \%$ 以下のばらつきであり, 再現性が よい. $\tau_{\mathrm{f}}$ は, 別途に求めたブラスティングのみの試験片 をねじり試験したときの結果である. 最大せん断応力に 換算して, 平均値と分散が示してある。活のばらつきと 同程度のばらつきで, 再現性がよい. $\tau_{\mathrm{f}}$ は, Fig. 4 に示し たように，接触による摩擦が原因と考えられる．溶射部 材の界面強度（ $\tau_{\mathrm{cr}}$ とする）は， $\tau_{\mathrm{f}}$ より小さければ $\tau_{\mathrm{cr}}$ と して見かけ上 $\tau_{\mathrm{t}}$ が得られる. 従って, 本試験方法では界 面強度 $\tau_{\mathrm{cr}}$ が $\tau_{\mathrm{f}}$ より大きい場合だけ, $\tau_{\mathrm{cr}}$ が求められる. 界面強度 $\tau_{\mathrm{cr}}$ が $\tau_{f}$ より大きい場合でも, 破断荷重に接触 

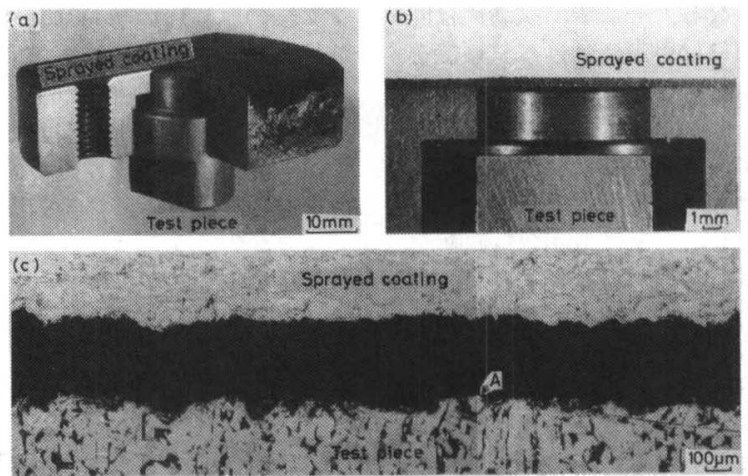

Fig. 5 Ruptured specimen: (a) the whole of specimen, (b) macroscopic view, (c) microscopic view.

Table 1 Experimental results.

\begin{tabular}{|c|c|c|c|c|}
\hline$\stackrel{d}{d}$ & $\begin{array}{c}\tau b \\
(\mathrm{MPa})\end{array}$ & $\underset{(\mathrm{MPa})}{\left(\tau_{b}\right)}$ & $\underset{(\mathrm{MPa})}{\tau,}$ & $\begin{array}{c}\tau_{0}-\tau_{1} \\
(\mathrm{MPa})\end{array}$ \\
\hline 6 & $\begin{array}{l}127 \\
121 \\
127\end{array}$ & $125 \pm 3.5$ & $37.1 \pm 8.7$ & 88 \\
\hline 10 & $\begin{array}{l}63 \\
60 \\
69\end{array}$ & $64 \pm 4.6$ & $15 \pm 4.7$ & 49 \\
\hline 15 & $\begin{array}{l}40 \\
43 \\
36\end{array}$ & $40 \pm 3.5$ & $6 \pm 3.3$ & 34 \\
\hline
\end{tabular}

摩擦力が寄与しているか否かの問題が残されている.そ こで, せん断強度として $\tau_{\mathrm{b}}$ 以外に, 摩擦力の効果を除い た $\left(\tau_{\mathrm{b}}-\tau_{\mathrm{f}}\right)$ も示す.また, 破断強度は試験片直径の影響 を受けており， $d$ が大きいほど小さい応力で破壊してい る.

\section{4.エネルギ一解放率に注目した強度評価}

\section{1 エネルギー解放率に注目する利点}

溶射界面には, Figs. 4, 5 に示したようにブラスティン グのために山凸が生じている. 模式図を Fig. 6 に示すよ うに, 試験片の溶射界面の外周部には, (b), (c), (d)に示 すように種々の角度 $\theta$ が存在しており, $\theta$ に応じて, 応 力の特異項が無数に存在することになる ${ }^{11}$. また, 界面形 状を(b)のように直線と仮定しても, 前報8)で明らかにし たように, 溶射部材の試験片では応力の特異項は一般に 2 つ存在し ${ }^{11}$, 応力值を一つの特異項で規定できないた め, 強度評価が困難と思われる。

界面端部の界面上にき裂が存在していると仮定したな らば, (e)に示すように角度 $\theta$ の変動による応力特異性の 花化はき裂の存在による応力の特異性に比べて小さい.

また, 一般に, 有限要素法により数值解析した場合に は, エネルギー解放率の計算精度は応力拡大係数の計算 精度よりも高い12). 従って, 工学的にはき裂を界面に仮定 して, 強度評価のパラメーターとして, 9值が有効か否 かを検討することは意義があると思われる。

\section{2 エネルギー解放率の計算方法と計算精度}

計算には, 四角形 2 次要素の有限要素法を用いた. 計 算は弾性条件で行い, 弾性状態では $\mathrm{J}$ 積分值が9值に等

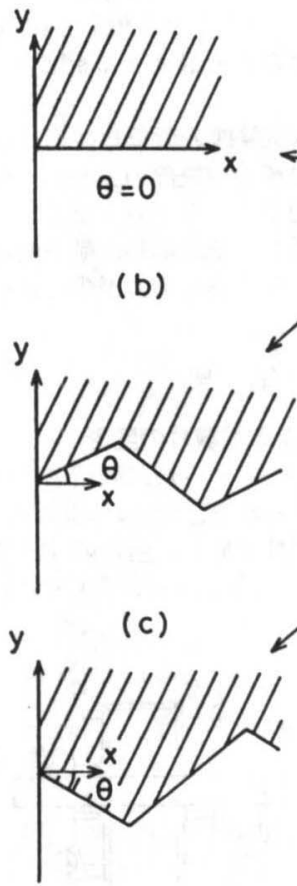

(d)

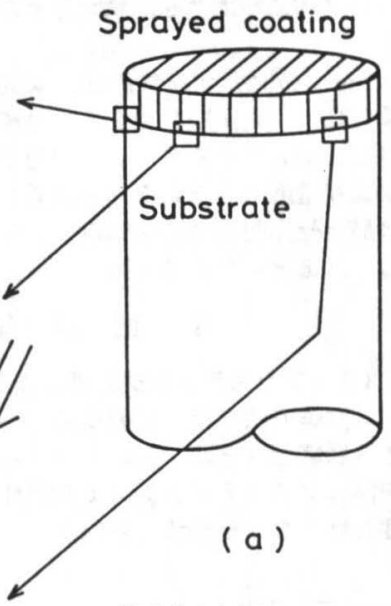

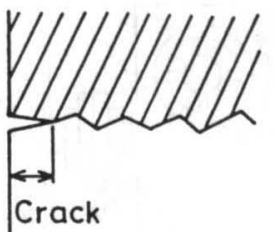

(e)
Fig. 6 Schematic diagram of the interface of sprayed coating and substrate surface: (a) macroscopic view, (b), (c) and (d) microscopic view, (e) imaginary crack.

しいことを利用して， $\mathrm{J}$ 積分值を積分径路から求めて， 9 値とした.

Fig. 7 に, 積分径路および計算値を調へたときに用い た要素分割図の一例を示す. 図中の(1)，(2)，(3)，(4)，(5) は用いた積分径路を示す. 溶射部材の J 積分値の理論値 がないため, 均一材の丸棒に円周切欠か中央切欠が存在 する場合を対象として, 計算値の妥当性を検討した. 計 算結果を示した Table 2 では, $J$ 值から応力拡大係数を 算出し $(P K$ とする), 理論值 $(K$ とする) と比較してい る. 軸引張では垂直応力が $1 \mathrm{MPa}$ 、ねじりでは最大せん 断応力が $1 \mathrm{MPa}$ の時の值である. $a$ はき裂長さである. 表中の(1), (2), (3), (4), (5)は, Fig.7 の積分径路(1), (2), 
(3)，(4)，(5)を用いたときの計算結果である．計算結果に 及注す積分径路の影響は $2 \%$ 程度であることが分かる。

理論值と計算值との比較より，本論文で用いた計算法 では約 $8 \%$ 誤差が存在している.

\section{3 残留応力によるエネルギ一解放率が一定となる} 試験片形状

Fig. 8 (a)に，残留応力により生じるエネルギー解放率 9值に及ほす試験片寸法の影響を示す。図中に示す模式 図は, 計算した対称形の試験片の片測の形状を示す。試 験片の半幅 $b$, 試験片長さ $h^{\mathrm{B}}$, 溶射皮膜厚さ $h^{\mathrm{A}}$, 材料定
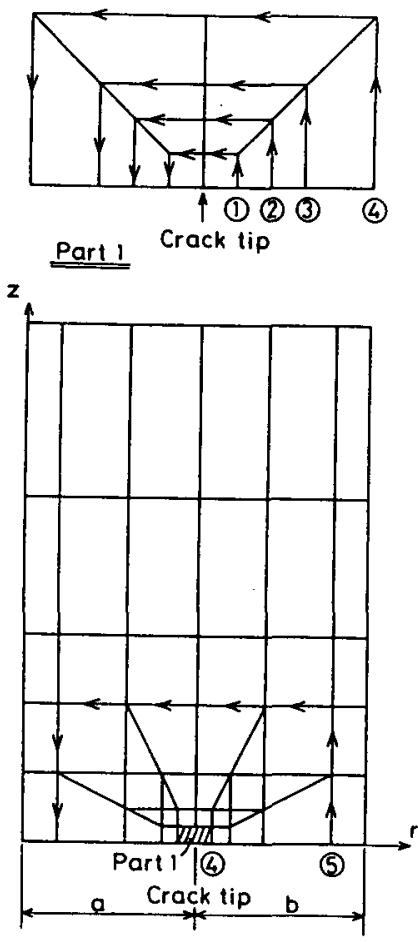

Fig. 7 Mesh division

Table 2 Comparison between theoretical value and numerical calculation of stress intensity factor. $(E=20000 \mathrm{MPa}, \nu=$ 0.3 , stress $=1 \mathrm{MPa}$ )

\begin{tabular}{|c|c|c|c|c|}
\hline & $\begin{array}{l}\text { PX }(\text { FEM }) \\
(M P a \sqrt{\mathrm{AM}})\end{array}$ & $\begin{array}{l}\text { K(Theory) } \\
\text { (MPa } \sqrt{\text { Min }})\end{array}$ & $\begin{array}{l}\text { Error } \\
\mathrm{PK}-\mathrm{K}: / \mathrm{K}\end{array}$ & other \\
\hline $\begin{array}{c}\text { Penny shaped crack } \\
a=5 \mathrm{ma}, d=20 \mathrm{ma}\end{array}$ & $\begin{array}{ll}\text { (1) } & 2.59 \\
\text { ( } & 2.59 \\
\text { (1) } & 2.57 \\
\text { (4) } & 2.56 \\
\text { (5) } & 2.54\end{array}$ & 2.73 & $\begin{array}{l}0.051 \\
0.051 \\
0.050 \\
0.062 \\
0.070\end{array}$ & \multirow[t]{2}{*}{$\begin{array}{l}\operatorname{lxja} \\
\log 0\end{array}$} \\
\hline $\begin{array}{c}\text { Circular crack } \\
a=5 \mathrm{an}, d=20 \mathrm{man}\end{array}$ & $\begin{array}{ll}\text { (1) } & 7.22 \\
\text { (2) } & 7.24 \\
\text { (4) } & 7.34 \\
(4) & 7.43 \\
\text { (6) } & 7.34\end{array}$ & 7.69 & $\begin{array}{l}\text { f. } 061 \\
0.059 \\
0.046 \\
0.034 \\
0.045\end{array}$ & \\
\hline $\begin{array}{c}\text { Circular crack } \\
\quad \mathrm{a}=5 \mathrm{~mm}, \mathrm{~d}=28 \mathrm{~cm}\end{array}$ & (1) $\quad 5.74$ & 5.03 & 0.032 & \\
\hline $\begin{array}{c}\text { Penny shaped crack } \\
a=6 \mathrm{mn}, d=24 \text { m na }\end{array}$ & (3) 0.907 & 0.930 & 0.025 & Torsion \\
\hline $\begin{aligned} & \text { Circular crack } \\
& a=2 \mathrm{am}, d=24 \mathrm{~mm} \\
& \mathrm{a}=6 \mathrm{~mm}, d=24 \mathrm{~mm}\end{aligned}$ & (3) 12.83 & $\begin{array}{r}3.07 \\
12.95\end{array}$ & $\begin{array}{l}0.078 \\
0.053\end{array}$ & \\
\hline
\end{tabular}

数を図中に示す。縦軸は溶射部材のヤング率 $E^{\mathrm{A}}$, 線膨張 係数 $\alpha^{\mathrm{A}}$, 溶射皮膜の温度上輩 $T$, 仮想き裂長さ $a$ で,無 次元化した9值である。横軸は皮膜厚さに対する試験片 半幅の比 $b / h^{\mathrm{A}}$ である. ヤング率の比 $E^{\mathrm{B}} / E^{\mathrm{A}}=1,2$, 仮 想き裂長さ $a=0.04,0.06 \mathrm{~mm}\left(a / h^{A}=0.08,0.12\right)$ が 変化しても， $b / h^{\mathrm{A}}$ が 4 以上で，9值は一定值となってい る、この結果は既報 ${ }^{13)} の ~ a=0.001 \mathrm{~mm}\left(a / h^{\mathrm{A}}=0.05\right)$ で の結果と一致している.一般に, 溶射皮膜のヤング率 $E^{A}$ がサブストレイトのヤング率 $E^{\mathrm{B}}$ より小さいことを考虑 すれば14)，ヤング率の比 $E^{\mathrm{B}} / E^{\mathrm{A}}$ は 1 より大きくなり, b/ $h^{\wedge}$ が 4 以上で9值は最大值になっている.

Fig. 8(b)に，9值に及ほすす試験片長さ $h^{\mathrm{B}}$ の影響を示

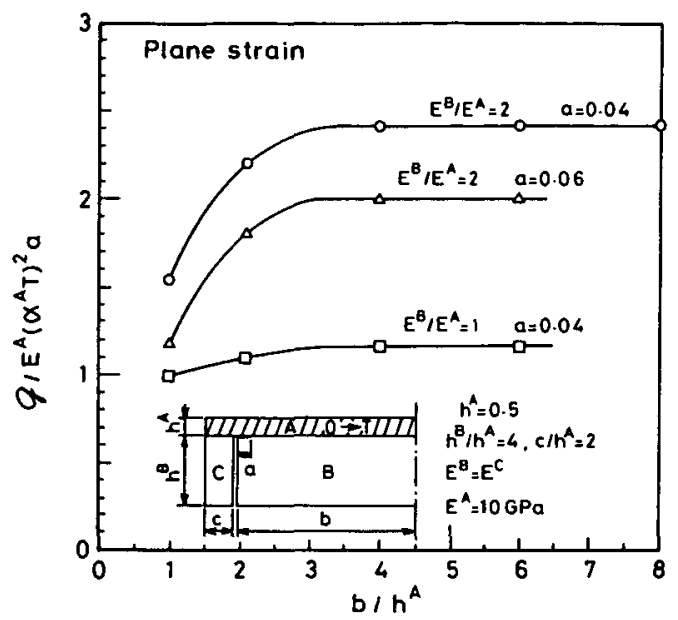

(a)

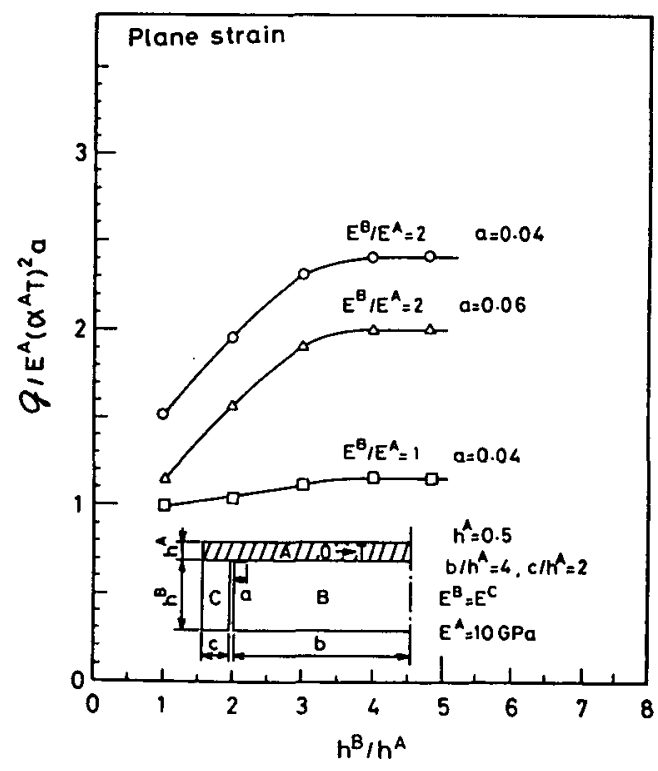

(b)

Fig. 8 Effect of specimen size on the energy release rate: (a) ratio of $\mathrm{b}$ and $h^{\mathrm{A}}$, (b) ratio of $h^{\mathrm{B}}$ and $h^{\mathrm{A}}$. 
す.計算条件は,Fig. 8(a)と同じである.図より，試験片 の長さ $h^{\mathrm{B}}$ が溶射皮膜の厚さ $h^{\mathrm{A}}$ の 4 倍以上では，9值は 一定值となっている。ヤング率の比 $E^{\mathrm{B}} / E^{\mathrm{A}}$ が 1 より大 きいことより， $h^{\mathrm{B}} / h^{\mathrm{A}}$ が 4 以上でのタ值は最大值になっ ている。

以上のことから, 試験片の半幅(インプラント試験片 では半径となる) $b$ が $h^{\mathrm{A} の ~} 4$ 倍以上で，かつ試験片の長 さ $h^{B}$ が $h^{\wedge}$ の 4 倍以上の条件を満たす試験片を用いる と, 残留応力による9値は一定值となり，しかも最大值 になっていることが分かる。

\section{4 強度評価に及ぼす仮想き裂長さの影䇒}

溶射皮膜の強度評価をタ值で行う場合には，基準とな る試験片の9值（91とする）と強度評価をする対象物の 9 值 $\left(9_{\mathrm{N}}\right.$ とする) の比の平方根 $\sqrt{9_{1} / 9_{N}}$ に仮想き裂長 さ $a$ が影響を与えないことが必要である(平方根 $\sqrt{9_{1} / 9_{\mathrm{N}}}$ を用いた理由は，き裂に扔いて，9が応力拡大 係数 $K$ の平方と結び付いていること，及び $K$ が外応力 $\sigma$ と線形関係にあることより，Яを $\sigma と$ 結び付けるため に，9の平方根を用いた)。

9值に及济す仮想き裂長さ $a$ の影響を調べた結果を, Table 3 に示す。ポアソン比 $v$ は, 多くの物質で 0.25 か ら0.35の間にあるので, 0.3 と定にした。形状は円周切 久の円柱で, 荷重負荷形式は引張である.D2 は試験片直 径が $2 \mathrm{~mm}, \mathrm{D} 4$ は $4 \mathrm{~mm}$ を, t0.5 は溶射皮膜の厚さが 0.5 $\mathrm{mm}$ を, t1 は $1 \mathrm{~mm}$ を意味する.サブストレイトと溶射 皮膜のヤング率の比 $E^{\mathrm{B}} / E^{\mathrm{A}} 0.2,10$, き裂長さ $a$ を $0.04,0.06 \mathrm{~mm}\left(a / h^{\mathrm{A}}<0.12\right.$ の範囲) と変化させた. 9 1. として, D2t0.5 の9值を選んだ. $\sqrt{9_{\mathrm{I}} / 9_{\mathrm{N}}}$ はヤング率の 比が変化しても，仮想き裂長さ $a$ の影響をあまり受けて いないことが分かる.従って, 工学的には $a / h^{A}<0.120$ 範围にある仮想き裂長さ $a$ を用いて，9值で強度評価で きる可能性がある。また, 表よりヤング率の比 $E^{\mathrm{B}} / E^{\mathrm{A}}$ が 0.2 から 10 と50倍も変化している割には， $\sqrt{9_{1} / 9_{\mathrm{N}}}$ 值の 変化が小さいことがわかる。

\section{5 q值による強度評価}

エネルギー解放率＼cjkstart值を強度評偭パラメータとして選 んだときには次の難しい問題がある。すなわち，9值を モードI，モードIIに分離して，モードIに起因するエ
ネルギー解放率を限界值に用いるのか，モード I 、モー ドIIの和である9值を限界值に用いるのか明かでな ( ${ }^{6)}$. 従って, 残留応力により生じた 值 $\left(9_{\mathrm{R}}\right.$ とする) と強度評価試験により得られた 值 $\left(9_{\mathrm{L}}\right.$ とする)をどの 様に取り扱うかという問題が未解決である．特に，残留 応力による9 $\mathrm{R}$ 值は絶対值を求めることは困難である. しかし，4.3項で明らかにしたように，強度評価を行う溶 射部材と試験片に生じている残留応力による $\mathrm{R}$ 值が一 定值であれば，同一の強度評価試験方法により得られた 外荷重によるタ!值が一定になる条件で, 強度評価が出 来る可能性がある。

Table 4 に，ねじり試験結果のせん断強度 $\tau_{\mathrm{b}},\left(\tau_{\mathrm{b}}-\tau_{f}\right)$ と $9_{\mathrm{L}}$ 值加強度評価した $P \tau_{\mathrm{b}}, P\left(\tau_{\mathrm{b}}-\tau_{\mathrm{f}}\right)$ を示寸。

9. 值は最大せん断応力 $\tau_{\max }=1 \mathrm{MPa}$ のときのエネル ギー解放率である．仮想き裂長さを $0.04 \mathrm{~mm}$ ，サブスト レイトのヤング率を196 GPa，実験に使用した溶射皮膜 のヤング率を $98 \mathrm{GPa}^{15)}$, ポアソン比を 0.3 とて, 9 $\mathrm{L}$ 值 を計算した。

$d=15 \mathrm{~mm}$ のデータを基準に， $d=10,6 \mathrm{~mm}$ のせん断 強度 $\boldsymbol{\tau}_{\mathrm{b}}=64 \mathrm{MPa}, 125 \mathrm{MPa}$ を予測すると $58 \mathrm{MPa}, 89$ $\mathrm{MPa}$ となり，摩擦力によるせん断力を除いたせん断強度 $\left(\tau_{\mathrm{b}}-\tau_{\mathrm{f}}\right)=49 \mathrm{MPa}, 88 \mathrm{MPa}$ 予測すると $49 \mathrm{MPa}, 75$ $\mathrm{MPa}$ となった。予測誤差はそれぞれ $9 ， 29 ， 0 ， 15 \%$ あ る、表より，せん断強度 $\left(\tau_{\mathrm{b}}-\tau_{\mathrm{i}}\right)$ はタ值により評価でき ていると思われる.せん断強度坫においては， $d=6 \mathrm{~mm}$ の実験值がタ值により説明できていない.

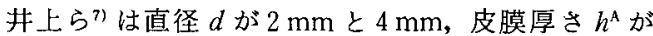
$0.5 \mathrm{~mm}$ と $1 \mathrm{~mm}$ のインプラント型の引張試験片の強度 試験を行っている.彼らの実験ではプラスティングを数 秒にして，ブラスティングの円凸による摩擦力が生じな いように注意が払われている16). Table 5 に実験結果 $\sigma_{g}$ と $\sqrt{9_{\mathrm{L}}}$ 值による予測值 $P \sigma_{g}$ を示す. $9 \mathrm{~L}$ 值の計算には溶 射皮膜のヤング率の情報が必要であるが，4.4 項で記述 したように，ヤング率の比は $\sqrt{9 \mathrm{~L}}$ 值の比に余り影響を 与えないため, Table $3 の a=0.04 \mathrm{~mm}$ での $\sqrt{\boldsymbol{q}_{\mathrm{L}}}$ 値の 比を使用した。

$\sigma_{g}$ の欄に,引張強度の平均值と分散を示す。溶射材料 の種類と溶射皮膜の厚さ別に，直径 $4 \mathrm{~mm}$ の引張強度の

Table 3 Effect of crack length on the ratio of square root of energy release rate. $\sqrt{9_{N} / \overline{9}_{1}}$ obtained from the difference of specimen sizes. $\left(E^{\mathrm{A}}=200 \mathrm{GPa}, \nu^{\mathrm{A}}=\nu^{\mathrm{B}}=0.3\right)$

\begin{tabular}{|c|c|c|c|c|c|c|c|c|c|c|c|}
\hline & & \multicolumn{4}{|c|}{$E^{8} / E^{a}=10$} & \multirow{2}{*}{\multicolumn{2}{|c|}{$a=0.04 \mathrm{an}$}} & \multicolumn{4}{|c|}{$E^{B} / E^{A}=0.2$} \\
\hline & & \multicolumn{2}{|c|}{$a=0.04 \mathrm{~mm}$} & \multicolumn{2}{|c|}{$a=0.06$ m } & & & \multicolumn{2}{|c|}{$\mathrm{a}=0.04 \mathrm{~mm}$} & \multicolumn{2}{|c|}{$a=0.06 \mathrm{~mm}$} \\
\hline & & $\begin{array}{l}E^{B} 8 \\
\left(a^{n}\right)\end{array}$ & $\sqrt{8,18} \mathrm{~N}$ & $\begin{array}{l}\mathrm{E}^{\mathrm{B}} \mathrm{g} \\
(\mathrm{Am})\end{array}$ & $\sqrt{8,78}$ & $\begin{array}{l}\mathrm{E}^{\mathrm{\theta}} \mathrm{g} \\
(\mathrm{m} \mathrm{m})\end{array}$ & $\sqrt{91 / 8} \mathrm{~N}$ & $\begin{array}{l}E^{B} g \\
(\mathrm{na})\end{array}$ & $\sqrt{9_{1} / \theta_{N}}$ & 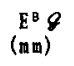 & $\sqrt{8, / 8 N}$ \\
\hline $\begin{array}{l}1 \\
2 \\
3 \\
4\end{array}$ & $\begin{array}{l}\text { D2t0.5 } \\
\text { D4to.5 } \\
\text { D2t1 } \\
\text { D4t1 }\end{array}$ & $\begin{array}{r}12.91 \\
52.03 \\
7.22 \\
28.68\end{array}$ & $\begin{array}{l}1.0 \\
0.50 \\
1.34 \\
0.67\end{array}$ & $\begin{array}{r}18.01 \\
71.31 \\
9.75 \\
38.17\end{array}$ & $\begin{array}{l}1.0 \\
0.50 \\
1.36 \\
0.69\end{array}$ & $\begin{array}{r}2.89 \\
11.04 \\
1.60 \\
5.86\end{array}$ & $\begin{array}{l}1.0 \\
0.51 \\
1.34 \\
0.70\end{array}$ & $\begin{array}{l}0.461 \\
1.384 \\
0.267 \\
0.692\end{array}$ & $\begin{array}{l}1.0 \\
0.58 \\
1.31 \\
0.82\end{array}$ & $\begin{array}{l}0.536 \\
1.711 \\
0.343 \\
0.869\end{array}$ & $\begin{array}{l}1.0 \\
0.56 \\
1.25 \\
0.79\end{array}$ \\
\hline
\end{tabular}

Table 4 Comparison between predicted value and experimental result of stress. $\left(E^{A}=196 \mathrm{GPa}\right.$, $\left.E^{\mathrm{B}}=98 \mathrm{GPa}, \nu=0.3, \tau_{\max }=1 \mathrm{MPa}, \mathrm{a}=0.04 \mathrm{~mm}\right)$

\begin{tabular}{|c|c|c|c|c|c|c|c|c|}
\hline (in) & $P_{1}(\underset{(\mathrm{MPa}=1 \mathrm{max})}{(\mathrm{MPa})}$ & 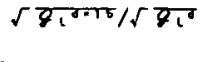 & $\begin{array}{l}\tau_{b} \\
(\mathrm{MPa})\end{array}$ & $\begin{array}{l}P \tau \\
\left(M P_{a}\right)\end{array}$ & $\frac{\left|\mathrm{P} \tau_{b}-\tau_{b}\right|}{\tau_{0}}$ & $\begin{aligned} \tau & -\tau \\
(\mathrm{MPa}) & \end{aligned}$ & $\begin{array}{l}P\left(\tau, \tau_{0}-\tau\right) \\
\left(\mathrm{MPa}_{\mathrm{P}}\right)\end{array}$ & $\frac{\left|P\left(\tau_{b}-\tau_{t}\right)-\left(\tau_{b}-\tau_{1}\right)\right|}{\left|\left(\tau_{b}-\tau_{1}\right)\right|}$ \\
\hline $\begin{array}{r}6 \\
10 \\
15\end{array}$ & $\begin{array}{l}\text { 1. } 407 \times 10^{-8} \\
\text { 3. } 333 \times 10^{-6} \\
\text { 6. } 952 \times 10^{-6}\end{array}$ & $\begin{array}{l}2.22 \\
1.44 \\
1\end{array}$ & $\begin{array}{r}125 \\
64 \\
40\end{array}$ & $\begin{array}{l}89 \\
58 \\
40\end{array}$ & $\begin{array}{l}0.29 \\
0.09 \\
1\end{array}$ & $\begin{array}{l}88 \\
49 \\
34\end{array}$ & $\begin{array}{l}75 \\
49 \\
34\end{array}$ & $\begin{array}{l}\text { 0. } 15 \\
0.00 \\
0.00\end{array}$ \\
\hline
\end{tabular}


Table 5 Tensile strength estimated from the energy release rate.

\begin{tabular}{|c|c|c|c|c|c|}
\hline & $\sqrt{8 L^{d=4}} / \sqrt{8 L^{d}}$ & $\begin{array}{c}\sigma o \\
(\mathrm{MPa})\end{array}$ & $\begin{array}{l}P \sigma a \\
(M P a)\end{array}$ & $\frac{P \sigma_{0}-\sigma_{0} \mid}{\sigma_{0}}$ & other \\
\hline $\begin{array}{l}\text { D2to. } 5 \\
\text { D4to. } 5\end{array}$ & $\begin{array}{l}2.01 \\
1\end{array}$ & $\begin{array}{l}31.4 \pm 1.8 \\
15.4 \pm 0.5\end{array}$ & $\begin{array}{l}31.0 \\
15.4\end{array}$ & $\begin{array}{l}0.01 \\
0\end{array}$ & \multirow[t]{2}{*}{ FCD/CONiCrAlY } \\
\hline $\begin{array}{l}\text { D2t1 } \\
\text { D4t } 1\end{array}$ & $\begin{array}{l}1.99 \\
1\end{array}$ & $\begin{array}{l}35.4 \pm 7.5 \\
21.0 \pm 5.1\end{array}$ & $\begin{array}{l}41.8 \\
21.0\end{array}$ & $\begin{array}{l}0.18 \\
0\end{array}$ & \\
\hline $\begin{array}{l}\text { D2t l } \\
\text { D4t l }\end{array}$ & $\begin{array}{l}1.99 \\
1\end{array}$ & $\begin{array}{l}91.9 \pm 5.0 \\
50.7 \pm 6.1\end{array}$ & $\begin{array}{r}100.9 \\
50.7\end{array}$ & $\begin{array}{l}0.10 \\
0\end{array}$ & $\mathrm{FCD} / 80 \mathrm{Ni}-20 \mathrm{Cr}$ \\
\hline $\begin{array}{l}\text { D2to. } 5 \\
\text { D4to. } 5\end{array}$ & $\begin{array}{l}2.01 \\
1\end{array}$ & $\begin{array}{l}8.6 \pm 1.7 \\
3.8 \pm 0.5\end{array}$ & $\begin{array}{l}7.6 \\
3.8\end{array}$ & $\begin{array}{l}0.12 \\
0\end{array}$ & $\mathrm{SUS} / \mathrm{ZrO}_{2} .8 \mathrm{Y}_{2} \mathrm{O}_{3}$ \\
\hline
\end{tabular}

平均値を基準にして $\sqrt{9\llcorner}$ 值の比率から予測した強度を $P \sigma_{g}$ に示す.予測誤差は, FCD/CoNiCrAlY の D2t1 の場 合に最も大きく，約18\%である．他の条件ではほとんど 10\%以下の誤差で予測されており，予測精度は良好であ る. 井上らのデータが $\sqrt{q_{\mathrm{L}}}$ 值の比で評価できていると 思われる。

以上のように，エネルギー解放率をパラメータとする 強度評価方法は，引張試験・㸚じり試験ともに高々 $20 \%$ の誤差で整理されており, 工学的に有効な強度評価方法 であると思われる。

\section{5. 結 論}

溶射部材の強度評価を行う試験方法として，ねじり試 験法を提案し，実験結果を用いて強度評価の考察を行っ た。得られた結論を以下に示す。

1）自作したねじり試験機で溶射部材をねじり試験し た結果，10\%以下のばらつきで，再現性のよい実験結果 を得ることができた。

2）ブラスティングにより生じる塑性変形は，強度評 価の試験結果に影響を及ほす危険性のあることを指摘し た.

3）インプラント試験片の半径と試験片長さが溶射皮 膜厚さの 4 倍以上のとき, 残留応力によるエネルギ一解 放率 $\boldsymbol{R}_{\mathrm{R}}$ は試験片の大きさの影響を受けなくなる.

4）エネルギー解放率による強度評価は，ねじり試 験・引張試験ともに有効である。

\section{参 考 文 献}

1) 例えば JIS H8304-1990

2) D. Bohme: Modification of a known and development of a new testing methode for the determination of the adhesive strength of thermal sprayed coatings.

3) DIN 50160

4）日本機械学会，第68期全国大会講演会，1990東北大学.

5）服部敏雄，坂田荘司，初田俊男，坂上元：応力特異場パラメ一多 を用いた接着界面強度評価, 日本機械学会論文炛 ( A 編), $\mathrm{Vol}$ 54, No. 499 (1988), p. 597-602.

6) 結城良治, 鄭南龍, 石川晴雄, 中野禅：接着継手の混合モード破 櫒基準，材料，Vol. 39，No. 443 (1990)，p. 1095-1100.

7) 井上好章, 小野豊明, 納富啓, 出羽昭夫, 豊田政男, 塚本光夫： 引張り型ピンテストによるプラズマ溶射皮膜の界面強度評価 法, 溶接学会全国大会講演概要，第47集 $(1990)$, p. 242 。

8）寺崎俊夫, 炏山哲也, 平居孝之, 瀬尾健二：溶射材に生じる界面 端部近傍の残留応力について, 溶接学会論文集, Vol. 9, No. 3 (1991), p. 112-118.

9）寺崎俊夫，秋山暂也，瀨尾健二，平居孝之：界面端部近傍に生ず る残留応力について, 溶接学会論文集, Vol. 8, No.4 (1990), p. $478-492$.

10）寺崎俊夫, 秋山哲也,金子友義：溶射材の界面強度を評価する試 験方法の提案，溶接学会全国大会講演概要，第47集 (1990)，p. 248.

11) A.K. Rao: Stress Concentrations and Singularities at Interface Corners, ZAMM 51 (1971), 395-406.

12) 白鳥正樹, 三好俊郎, 松下久雄：数値破烄力学, 1988 , 実教出版.

13）寺崎俊夫, 秋山哲也，瀬尾健二：異材継手の界面端部に存在する き裂の9值について, 溶接構造委員会 WD-7-90。

14）納富辟, 児玉克, 小野豊明, 井上好章, 川野正和, 谷昇：プラス マ溶射皮膜の残留応力測定に関する研究，溶接学会諭文集： Vol. 6, No. 3 (1988), p. 341-347.

15）福田敬二, 金裕哲, 秋山哲也，寺崎俊夫：固有ひずみの概念によ る溶射材に生しる残留応力の推定方法について, 溶射, Vol. 27, No. 3 (1990), p. 1-8.

16) 井上好章氏の私信. 